Pontifícia Universidade Católica $_{\text {Do Rio de Janeiro }}$

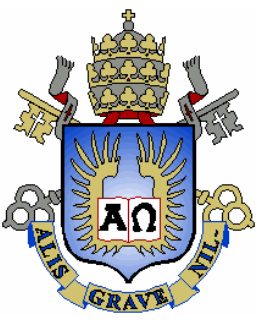

Luciana Montenegro da Silva Pereira

\title{
A forma como fundamento no design: permanências e alterações
}

Tese de Doutorado

Tese apresentada ao Programa de Pós-graduação em Design da PUC-Rio como requisito parcial para obtenção do título de Doutor em Design.

Orientador: Denise Berruezo Portinari Co-orientador: João de Souza Leite 


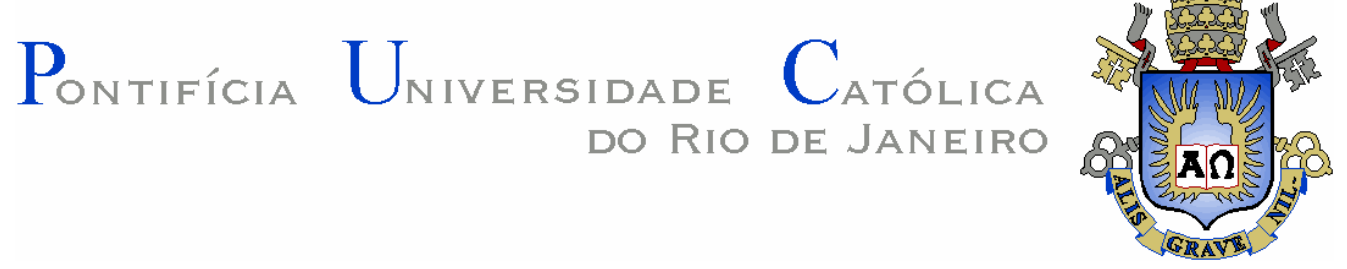

Luciana Montenegro da Silva Pereira

\section{A forma como fundamento no design: permanências e alterações}

Tese apresentada ao Programa de Pós-graduação em Design da PUC-Rio como requisito parcial para obtenção do título de Doutor em Design. Aprovada pela Comissão Examinadora abaixo assinada.

Denise Berruezo Portinari Orientador

Departamento de Artes \& Design - PUC-Rio

João de Souza Leite

Co-orientador

Departamento de Artes \& Design - PUC-Rio

Jofre Silva

Universidade Anhembi Morumbi

Washington Dias Lessa

ESDI - UERJ

Rita Maria de Souza Couto

Departamento de Artes \& Design - PUC-Rio

Luiz Antonio Luzio Coelho

Departamento de Artes \& Design - PUC-Rio

Prof. Paulo Fernando Carneiro de Andrade Coordenador Setorial do Centro de Teologia e Ciências Humanas - PUC - Rio 
Todos os direitos reservados. É proibida a reprodução total ou parcial do trabalho sem autorização da universidade, da autora e do orientador.

\section{Luciana Montenegro da Silva Pereira}

Bacharel em Comunicação Visual (1990) e Mestre em Design pela PUC- Rio. Integrante do Laboratório da Representação Sensível (1999-2009) vinculado ao Departamento de Artes e Design da PUC- Rio - linha de pesquisa: morfologia. Docente do curso de Bacharelado em Design de Moda e dos cursos de Pós - graduação em Design de Moda e Design de Estamparia da Faculdade SENAICETIQT. Experiência em direção de arte, planejamento, desenvolvimento e implementação de projetos gráficos.

Ficha Catalográfica

Pereira, Luciana Montenegro da Silva

A forma como fundamento no design: permanências e alterações / Luciana Montenegro da Silva Pereira ; orientadora: Denise Berruezo Portinari ; co-orientador: João de Souza Leite. - 2009

157 f. : il. ; $30 \mathrm{~cm}$

Tese (Doutorado em Design)-Pontifícia Universidade Católica do Rio de Janeiro, Rio de Janeiro, 2009.

Inclui bibliografia

1. Artes - Teses. 2. Design. 3. Configuração. 4. Forma. 5. Objeto. I. Portinari, Denise Berruezo. II. Leite, João de Souza. III. Pontifícia Universidade Católica do Rio de Janeiro. Departamento de Artes \& Design. IV. Título.

CDD: 700 


\section{Agradecimentos}

Aos professores Denise Portinari e João de Souza Leite pelo direcionamento e inesgotável compreensão e apoio.

Ao professor Gustavo Amarante Bomfim (em memória), pelo privilégio de tê-lo conhecido.

A Pontifícia Universidade Católica do Rio de Janeiro e ao Departamento de Artes e Design desta instituição, minha casa de formação, pelo acolhimento, apoio e acompanhamento.

Aos integrantes da comissão examinadora pelas contribuições fornecidas.

A direção, coordenação e colegas da Faculdade SENAI-CETIQT, pelo apoio durante o doutorado.

A minha família e amigos, pela paciência, companheirismo e afeto. 


\section{Resumo}

Montenegro, Luciana; Portinari, Denise (orientadora). A forma como fundamento no design: permanências e alterações. Rio de Janeiro, 2009. 157p. Tese de Doutorado - Departamento de Artes e Design, Pontifícia Universidade Católica do Rio de Janeiro.

Este trabalho resulta de um estranhamento frente aos discursos de denegação da forma no design, originários do próprio campo e da observação da recorrência de dois fatores em seu percurso constitutivo (considerando a cronologia clássica ocidental): as discussões em torno da forma e ela própria. $\mathrm{O}$ objetivo é identificar uma possível rede de conceitos e fatores que orientam atualmente a forma no design e estabelecer reflexão crítica fortalecendo uma via de reflexão para o entendimento do campo, por meio do que é mais concreto e resistente no design: a forma - entendida neste trabalho como aparência visual, aspecto exterior de uma materialidade artificial (construída pelo homem) como resultado de um processo (de configuração) que considera inúmeros aspectos (objetivos e subjetivos). Para isso são examinadas argumentações, enunciados de agentes críticos e de agentes configuradores do meio material (arquitetura, artes, ênfase no design) que sustentaram, validaram ou difamaram a produção formal no design. A linearidade temporal auxilia a organização da narrativa e conduz a exposição dos enunciados, mas não de maneira impositiva ou rígida, já que eles podem ser deslocados de seu "tempo", aproximados a outros por modos de pensar a forma e são examinados em relação à tradição teórica (hipóteses, conceitos e premissas), considerando ainda os contextos culturais, sociais e ambientais diante do qual encontram sua legitimidade (ou não). Críticas, análises e argumentações de teóricos (independente da localização temporal), sobre o conteúdo dos enunciados tratados aqui, também constituem o trabalho e subsidiam a reflexão em torno do tratamento dado à forma.

\section{Palavras-chave}

Design; morfologia; forma; objeto. 


\section{Abstract}

Montenegro, Luciana; Portinari, Denise (advisor). The form as groundwork in design: permanencies and changes. Rio de Janeiro, 2009. 157p. Doctoral Thesis - Departamento de Artes e Design, Pontifícia Universidade Católica do Rio de Janeiro.

This work is the result of estrangement with regard to denial discourses of the form in Design, originated from the design field and from the observations of the recurrence of two factors in its constitutive pathway (considering the Western classical chronology): the discussions about the form and the form itself. The objective is to identify a possible network of concepts and factors that guide the actual form in design and establish a critical thought in order to strengthen a reflexive path to the understanding of this field, through what is the most concrete and resistant in design: the form - understood in this work as visual appearance, exterior aspect of an artificial materiality (built by men) as a result of a process (of configuration) that considers many (objective and subjective) aspects. For this, an examination of arguments - enunciation of critical and configurative agents of the material environment (architecture, arts, emphasis on design) that sustained, validated or defamed the formal production in design - is done. The temporal linearity supports the organization of narrative and leads the exposure of enunciations, but not in a rigid or imposed manner, as they can be moved from their "time", approximated to others, by ways of thinking the form, and are examined regarding the theoretical tradition (hypotheses, concepts and assumptions), also considering the cultural, social and environmental contexts where they meet their legitimacy (or not). Theorists' criticism, analysis and arguments (regardless the time) about the content of the enunciations mentioned here also constitute the work and support the reflection on the treatment given to the form.

\section{keywords}

Design; configuration; form; object 


\section{Sumário}

$\begin{array}{ll}\text { 1. Introdução } & 8\end{array}$

2. O construtor moderno 13

2.1. Breve introdução ao pensamento construtivo/abstrato 14

2.2. Ordem clássica e abstração 20

2.3. A realidade da construção 28

2.4. A construção como programa 38

3. Regras de um modelo "ideal" 54

3.1. Racionalidade como princípio funcional 55

3.2. Embates sobre a produtividade em solo alemão 61

3.2. A forma moral: útil e funcional 72

4. O funcionalismo como estilo 83

4.1. A internacionalização do modelo 83

4.2. Funcionalidade para a massa 103

5. Desmonte e reparação 112

5.1. Tensão como sintoma 112

5.2. Conceitos em discussão 119

5.3. Tudo vira moda e tudo vira imagem 128

5.4. Múltiplos enfoques como parâmetro formal 135

6. Considerações finais 145

7. Bibliografia 